\title{
FAKTOR-FAKTOR YANG MEMPENGARUHI PERILAKU MASYARAKAT DALAM PENCEGAHAN PENULARAN COVID-19
}

\author{
Erika Untari Dewi* \\ *STIKes William Booth Surabaya, Jl.Cimanuk no.20 Surabaya. \\ E-mail : untarierika@yahoo.co.id
}

\begin{abstract}
ABSTRAK
Pencegahan dan penanggulangan penyakit yang penting adalah dengan cara memutus rantai penularan, yaitu dengan menghentikan agen masuk ke pejamu dan pencegahan yang mengarah pada upaya penanggulangan faktor risiko penyakit, seperti perilaku yang merupakan akumulasi dari pengetahuan dan sikap terhadap kesehatan seseorang untuk terbebas dari penyakit. Tujuan dari penelitian ini adalah untuk mengidentifikasi faktor-faktor yang mempengaruhi perilaku masyarakat dalam pencegahan penularan Covid-19. Desain yang digunakan pada penelitian ini deskriptif korelasi. Dalam penelitian ini menggunakan variabel independen dan dependen. Populasi dari Penelitian ini adalah masyarakat binaan Ners Stikes William Booth. Sampel yang digunakan 70 orang dengan menggunakan teknik total sampling. Pengambilan data dengan kuisioner. Data diperoleh dari hasil kuisoner, data yang terkumpul ditabulasi dengan tabel dan dikonfirmasikan dalam bentuk tabel. Dari hasil penelitian ini didapatkan hasil dari empat faktor yang mempengaruhi perilaku pencegahan penularan Covid-19 yakni factor usia, tingkat Pendidikan, pekerjaan, sosial ekonomi dan tingkat pengetahuan, ternyata faktor tingkat pengetahuan yang mempengaruhi perilaku pencegahan penularan Covid-19. Berdasarakan hasil penelitian ini sehingga untuk meningkatkan perilaku pencegahan penularan Covid-19 diperlukan Pendidikan kesehatan kepada masyarakat secara terusmenerus dan berkesinambungan.
\end{abstract}

Kata Kunci :. usia, tingkat Pendidikan, pekerjaan, sosial ekonomi, Covid-19, tingkat pengetahuan, perilaku

\begin{abstract}
Important prevention and control of disease is by breaking the chain of transmission, namely by stopping agents from entering the host and prevention which leads to efforts to overcome disease risk factors, such as behavior which is an accumulation of knowledge and attitudes towards one's health to be free from disease (2). The purpose of this study is to identify factors that influence people's behavior in preventing Covid-19 transmission. The design used in this research is descriptive correlation. In this study using independent and dependent variables. The population of this research is the Ners Stikes William Booth assisted community. The sample used 70 people using totaly sampling technique. Retrieval of data with a questionnaire. Data obtained from the questionnaire results, the collected data is tabulated with tables and confirmed in tabular form. From the results of this study, it was of the four factors that influence the behavior to prevent Covid-19 transmission, namely the factor of age, education level, occupation, socio-economy and level of knowledge, it turns out that the level of knowledge influences behavior to prevent Covid-19 transmission. Based on the results of this study, to improve the behavior to prevent Covid-19 transmission, health education to the community is needed continuously and continuously.
\end{abstract}

Keywords :: age, level of education, occupation, socioeconomic, Covid-19, level of knowledge, behavior

\section{Pendahuluan}

Virus penyebab COVID-19 ini dinamakan Sars-CoV-2.(SARS). Coronavirus Disease 2019 (COVID-19) adalah penyakit jenis baru yang belum pernah ditemukan. Penyakit Covid 19 bisa dicegah dan diatasi dengan cara memutus mata rantai penularan, yaitu dengan menghentikan agen masuk ke pejamu dan pencegahan yang mengarah pada upaya penanggulangan faktor risiko penyakit, 
seperti perilaku yang merupakan akumulasi dari pengetahuan dan sikap terhadap kesehatan seseorang untuk terbebas dari penyakit (2). Penambahan jumlah kasus COVID-19 berlangsung cukup cepat dan sudah terjadi penyebaran antar negara. Berdasarkan data hingga Maret 2020, secara global dilaporkan 90.870 kasus konfimasi di 72 negara dengan 3.112 kematian (CFR 3,4\%). Rincian negara dan jumlah kasus sebagai berikut: Republik Korea (4.812 kasus, 28 kematian), Jepang (268 kasus, 6 kematian), Singapura (108 kematian), Malaysia (29 kasus), Viet Nam (16 kasus), Filipina (3 kasus, 1 kematian), Kamboja (1 kasus), Pedoman Kesiapsiagaan Menghadapi Coronavirus Disease (COVID-19) Revisi ke-3 12 Thailand (43 kasus, 1 kasus), India (5 kasus), Indonesia (2 kasus). Hingga sampai saat ini jumlah peningkatan dari coronavirus ini semakin meningkat pesat setiap harinya dan memakan ribuan jiwa (Kemenkes, 2020). Hal yang dapat dilakukan supaya diri kita terlindungi adalah dengan menghindari kondisi atau tempat dimana Anda berpotensi terpapar virus tersebut. Berdasarkan Center for Disease Control and Prevention (CDC) suatu Lembaga di Amerika menyarankan beberapa hal untuk mencegah penyebaran penyakit pernapasan, yaitu: memperbanyak mencuci tangan dengan menggunakan air dan sabun minimal selama 20 detik, terutama pada saat sebelum kita keluar kamar mandi, sebelum makan; dan setelah kita buang ingus, atau batuk, atau bersin, apabila air dan sabun tidak tersedia, maka bisa digantikan dengan mengggunakan pembersih tangan yang mengandung alkohol dengan kadar kandungan alkohol minimal $60 \%$, menghindari menyentuh pada bagian wajah sebelum mencuci tangan, menghindari kontak dekat dan menghindari kerumunan, disarankan untuk jarak 1,5 meter. Tetap tinggal di rumah jika bila tidak ada kepentingan yang mendesak. Tutupi mulut Anda saat batuk dan bersin dengan menggunakan tisu, Sering membersihkan barang-barang serta perabotan di rumah Anda. Mematuhi protokol kesehatan untuk menghindari penularan Covid-19 sangat bergantung kepada perilaku kesehatan masyarakat. Perilaku masyarakat yang disarankan dalam program preventif kesehatan yang berpengaruh pada perilaku pencegahan penyakit terutama Covid-19 ini tentunya menjadi tanggung jawab berbagai pihak. Mencermati kondisi yang ada, sangat penting meninjau secara sistematis perilaku pencegahan Covid-19 dalam memtuhi protocol kesehatan yang telah ditetapkan pada masyarakat yang memiliki kepadatan tinggi.

\section{Metode Penelitian}

Berdasarkan tujuan penelitian, desain penelitian yang digunakan adalah desain deskriptif korelasi dimana desain penelitian yang digunakan bertujuan mendeskripsikan atau memaparkan peristiwa-peristiwa yang penting pada masa kini ( Nursalam, 2011 ). Tujuan penelitian adalah untuk menggambarkan Faktor-faktor yang mempengaruhi perilaku masyarakat dalam pencegahan penularan Covid-19. Variabel independent penelitian ini adalah faktor yang mempengaruhi yaitu tingkat Pendidikan, sosial ekonomi, jenis pekerjaan, umur, dan pengetahuan. Variabel dependent pada penelitian ini adalah perilaku masyarakat dalam pencegahan penularan.

Populasi dalam penelitian ini adalah seluruh masyarakat binaan Ners 2020 yang berjumlah 70 orang. Teknik sampling yang digunakan dalam penelitian ini adalah "Total Sampling" yaitu teknik penetapan sampel dengan cara memilih sampel dengan mengambil semua populasi yang ada. Instrumen yang digunakan dalam penelitian ini adalah kuisioner. Analisa data faktor yang mempengaruhi yakni factor usia, tingkat Pendidikan, jenis pekerjaan, sosial ekonomi dan tingkat pengetahuan terhadap perilaku dilakukan dengan cara uji statistik korelasi Spearmen dengan tingkat kemaknaan sebesar 0,05. 
Hasil Penelitian

Tabel 1 Karakteristik responden berdasarkan usia bulan November 2020

\begin{tabular}{|c|c|c|c|}
\hline No. & Usia & Jumlah & Prosentase \\
\hline 1 & $\begin{array}{c}17-25 \\
\text { th }\end{array}$ & 2 & 2,9 \\
\hline 2 & $26-35$ th & 9 & 12,9 \\
\hline 3 & $36-45$ th & 8 & 11,4 \\
\hline 4 & $46-55$ th & 29 & 41,4 \\
\hline 5 & $56-65$ th & 14 & 20,0 \\
\hline 6 & $>65$ th & 8 & 11,4 \\
\hline & Jumlah & 70 & $100 \%$ \\
\hline & P & \multicolumn{3}{|c|}{0,273} \\
\hline
\end{tabular}

Tabel 2 Karakteristik responden berdasarkan Pendidikan bulan November 2020

\begin{tabular}{|c|c|c|c|}
\hline No. & Pendidikan & Jumlah & Prosentase \\
\hline 1. & SD & 13 & $18,6 \%$ \\
\hline 2. & SMP & 10 & $14,3 \%$ \\
\hline 3. & SMA & 27 & $38,6 \%$ \\
\hline 4. & $\begin{array}{c}\text { Perguruan } \\
\text { Tinggi }\end{array}$ & 20 & $28,6 \%$ \\
\hline & Jumlah & 70 & $100 \%$ \\
\hline & p & \multicolumn{2}{|c|}{0,836} \\
\hline
\end{tabular}

Tabel 3 Karakteristik responden berdasarkan pekerjaan bulan November 2020

\begin{tabular}{|c|c|c|c|}
\hline No. & Pekerjaan & Jumlah & Prosentase \\
\hline 1. & Petani & 12 & $17,1 \%$ \\
\hline 2. & Wiraswasta & 19 & $27,1 \%$ \\
\hline 3. & Swasta & 27 & $36,6 \%$ \\
\hline 4. & PNS & 12 & $17,1 \%$ \\
\hline & Jumlah & 70 & $100 \%$ \\
\hline & p & \multicolumn{2}{|c|}{0,936} \\
\hline
\end{tabular}

Tabel 4 Karakteristik responden berdasarkan status ekonomi bulan November 2020

\begin{tabular}{|c|c|c|c|}
\hline No. & $\begin{array}{c}\text { Faktor } \\
\text { Status } \\
\text { ekonomi }\end{array}$ & Jumlah & Prosentase \\
\hline
\end{tabular}

\begin{tabular}{|c|c|c|c|}
\hline 1. & Rendah & 16 & $22,9 \%$ \\
\hline 2. & Cukup & 36 & $51,4 \%$ \\
\hline 3. & Tinggi & 18 & $25,7 \%$ \\
\hline & Jumlah & 70 & $100 \%$ \\
\hline & $\mathrm{p}$ & \multicolumn{2}{|c|}{0,192} \\
\hline
\end{tabular}

Tabel 5 Karakteristik responden berdasarkan faktor pengetahuan bulan November 2020

\begin{tabular}{|c|c|c|c|}
\hline No. & $\begin{array}{c}\text { Faktor } \\
\text { Pengetahuan }\end{array}$ & Jumlah & Prosentase \\
\hline 1. & Baik & 13 & $27,1 \%$ \\
\hline 2. & Cukup & 38 & $54,3 \%$ \\
\hline 3. & Kurang & 19 & $18,6 \%$ \\
\hline & Jumlah & 70 & $100 \%$ \\
\hline & $\mathrm{p}$ & \multicolumn{2}{|c|}{0,024} \\
\hline
\end{tabular}

Tabel 6 Karakteristik responden berdasarkan faktor perilaku pencegahan penularan Covid-19 bulan November 2020

\begin{tabular}{|c|c|c|c|}
\hline No. & Perilaku & Jumlah & Prosentase \\
\hline 1. & Baik & 42 & $60 \%$ \\
\hline 2. & Buruk & 28 & $40 \%$ \\
\hline & Jumlah & 70 & $100 \%$ \\
\hline
\end{tabular}

\section{Tabel 7}

\begin{tabular}{|c|c|c|}
\hline No. & $\begin{array}{c}\text { Faktor yang } \\
\text { mempengaruhi Perilaku }\end{array}$ & Nilai $\mathrm{p}$ \\
\hline 1. & Usia & 0,273 \\
\hline 2. & Tingkat Pendidikan & 0,386 \\
\hline 3. & Pekerjaan & 0,936 \\
\hline 4. & Status Ekonomi & 0,192 \\
\hline 5. & Pengetahuan & 0,024 \\
\hline
\end{tabular}

\section{Pembahasan}

Berdasarkan tabel 1 menunjukkan bahwa usia tidak mempengaruhi perilaku pencegahan penularan Covid-19 dengan nilai p: 0,273 lebih besar dari 0,05 sehingga $\mathrm{H} 0$ diterima yang berarti faktor usia tidak mempengaruhi perilaku pencegahan penularan Covid-19. Akan tetapi apabila dilihat dari tabel 1 karakteristik responden berdasarkan faktor usia didapatkan yang 
paling banyak usia 46 - 55 tahun yaitu sebanyak 29 orang ( $41,4 \%$ ) dan perilaku pencegahan penularan Covid-19 terbanyak baik yakni 42 orang $(60 \%)$ hal ini menunjukkan bahwa pada usia 46 - 55 tahun yakni usia lansia awal merupakan usia yang matang dan mampu untuk menerima pengetahuan serta mampu untuk menyelesaikan masalah dengan mekanisme pertahan diri yang baik. Pada situasi pandemi Covid-19 ini dibutuhkan kondisi psikologis yang baik untuk bisa menghadapi situasi yang kritis dan tetap waspada dengan menerapkan protocol kesehatan yang telah ditentukan untuk menghindari penularan penyakit ini.

Berdasarkan tabel 2 menunjukkan bahwa tingkat pendidikan tidak mempengaruhi perilaku pencegahan penularan Covid-19 dengan nilai p: 0,386 lebih besar dari 0,05 sehingga $\mathrm{H} 0$ diterima yang berarti faktor tingkat pendidikan tidak mempengaruhi perilaku pencegahan penularan Covid-19. Akan tetapi apabila dilihat dari tabel 1 karakteristik responden berdasarkan faktor tingkat pendidikan didapatkan yang paling banyak adalah Pendidikan SMA yaitu sebanyak 27 orang ( 38,6\% ) dan perilaku pencegahan penularan Covid-19 terbanyak baik yakni 42 orang (60\%). Menurut penelitian yang dilakukan Noghani dkk (2007) ditemukan adanya pengaruh positif dari tingkat pendidikan terhadap tingkat kualitas hidup namun tidak banyak Hal ini didukung oleh penelitian yang dilakukan Barbareschi dkk (2011) yang mengatakan bahwa terdapat perbandingan yang signifikan antara pasien yang berpendidikan tinggi dan rendah terlebih dalam masalah emosional dan dalam domain fisik dimana pada pasien yang berpendidikan tinggi kualitas hidupnya lebih baik dari waktu ke waktu. Tingkat pendidikan dapat mempengaruhi pola pikir seseorang sehingga sangat berdampak pada setiap aspek kehidupannya.

Berdasarkan tabel 3 menunjukkan bahwa pekerjaan tidak mempengaruhi perilaku pencegahan penularan Covid-19 dengan nilai $\mathrm{p}$ : 0,936 lebih besar dari 0,05 sehingga $\mathrm{H} 0$ diterima yang berarti faktor pekerjaan tidak mempengaruhi perilaku pencegahan penularan Covid-19. Akan tetapi apabila dilihat dari tabel 3 karakteristik responden berdasarkan faktor pekerjaan didapatkan yang paling banyak wiraswasta yaitu sebanyak 27 orang ( $36,6 \%$ ) dan perilaku pencegahan penularan Covid-19 terbanyak baik yakni 42 orang (60\%), hal ini terjadi kemungkinan dikarenakan pekerjaan wiraswasta menuntut untuk lebih banyak berhubungan dengan orang, contohnya pedagang sehingga mereka harus benar-benar melakukan protokol kesehatan untuk mencegah tertular dari penyakit ini.

Berdasarkan tabel 4 menunjukkan bahwa status ekonomi tidak mempengaruhi perilaku pencegahan penularan Covid-19 dengan nilai p: 0,192 lebih besar dari 0,05 sehingga $\mathrm{H} 0$ diterima yang berarti faktor status ekonomi tidak mempengaruhi perilaku pencegahan penularan Covid-19. Akan tetapi apabila dilihat dari tabel 4 karakteristik responden berdasarkan faktor status ekonomi didapatkan yang paling banyak cukup yaitu sebanyak 36 orang ( $51,4 \%$ ) dan perilaku pencegahan penularan Covid-19 terbanyak baik yakni 42 orang $(60 \%)$. Status ekonomi tidak mempengaruhi perilaku seseorang dalam mencegah penularan Covid 19 karena memang penyakit ini bisa menyerang siapa saja sehingga semua lapisan ekonomi tentunya akan memperhatikan protocol kesehatan untuk menvegah terjadinya penularan pada COVID-19.

Berdasarkan tabel 6 menunjukkan bahwa pengetahuan mempengaruhi perilaku pencegahan penularan Covid-19 dengan nilai p: 0,024 lebih kecil dari 0,05 sehingga $\mathrm{H} 0$ ditolak yang berarti faktor pengetahuan mempengaruhi perilaku pencegahan penularan Covid-19. Dari empat faktor yang mempengaruhi perilaku pencegahan penularan Covid-19 yakni factor usia, tingkat Pendidikan, pekerjaan, sosial ekonomi dan tingkat pengetahuan, ternyata faktor tingkat pengetahuan yang mempengaruhi perilaku pencegahan 
penularan Covid-19. Berdasarakan hasil penelitian ini sehingga untuk meningkatkan perilaku pencegahan penularan Covid-19 diperlukan Pendidikan kesehatan kepada masyarakat secara terus-menerus dan berkesinambungan supaya kepatuhan dalam menjalankan protocol kesehatan tidak kendor. Strategi dalam memberikan Pendidikan kesehatan untuk meningkatkan pengetahuan masyarakat bisa dilakukan dengan berbagai cara baik penyuluhan secara langsung maupun tidak langsung, dan juga bisa secara individu atau keluarga, kelompok kecil maupun kelompok besar.

\section{Kesimpulan}

1. Faktor usia tidak mempengaruhi perilaku pencegahan penularan Covid-19.

2. 2.Faktor tingkat pendidikan tidak mempengaruhi perilaku pencegahan penularan Covid-19.

3. Faktor jenis pekerjaan tidak mempengaruhi perilaku pencegahan penularan Covid-19.

4. Faktor sosial ekonomi tidak mempengaruhi perilaku pencegahan penularan Covid-19.

5. Faktor pengetahuan mempengaruhi perilaku pencegahan penularan Covid-19.

\section{DAFTAR PUSTAKA}

Atiqoh, NSari DP, Sholihah A. Hubungan antara pengetahuan masyarakat dengan kepatuhan penggunakan masker sebagai upaya pencegahan penyakit COVID-19 di Ngronggah. INFOKES J [Internet].

Kasjono HS, Kristiawan HB. Intisari Epidemiologi. Yoyakarta: Mitra Cendikia; 2008.

KemenkesRI. Pedoman pencegahan dan pengendalian coronavirus disesase (covid19). 5th ed. Jakarta: Kementeria Kesehatan RI; 2020.
KemenkesRI. Apa Yang Harus Dilakukan Masyarakat untuk cegah penularan Covid19 ? Jakarta: Kemenkes RI; 2020.

KemenkesRI. Studi Kepatuhan Masyarakat terhadap Himbauan Jaga Jarak dan Perilaku Hidup Bersih Selama Pandemi Covid192020. Jakarta; 2020

KemenkesRI. PMK RI No. 82 Thn 2014 tentang Penanggulangan Penyakit Menular. Kemenkes RI Republik Indonesia; 2014.

Masriadi. Epidemiologi Penyakit Menular. 2nd ed. Depok: PT RajaGrafindo Persada; 2017.

Notoatmojo, Soekidjo. 2007. Promosi Kesehatan dan Ilmu Perilaku. Jakarta : Rineta Cipta

Notoatmojo, Soekidjo. 2010. Metodologi Penelitian Kesehatan. Jakarta : Rineta Cipta

Nursalam. (2011). Konsep dan Penerapan Metodologi Penelitian Ilmu Keperawatan. Jakarta : Selemba Medika

Sudarma M. Sosiologi untuk Kesehatan. jakarta: Salemba Medika; 2008..

WHO. Pendidikan Kesehatan. Bandung \&: Penerbit ITB dan Penerbit Universitas Udayana; 1992 